\title{
Language and Thought Convergence (Poetic Grammar)
}

\author{
Antonio Domínguez Rey \\ Department of Spanish and General Linguistics, Faculty of Philology, Universidad Nacional de Educación a Distancia (UNED, Madrid), \\ Madrid, Spain
}

Email address:

adominguez@flog.uned.es

\section{To cite this article:}

Antonio Domínguez Rey. Language and Thought Convergence (Poetic Grammar). International Journal of Language and Linguistics. Special Issue: Linguistics of Saying. Vol. 3, No. 6-1, 2015, pp. 109-111.doi: 10.11648/j.ij11.s.2015030601.24

\begin{abstract}
The dichotomy between thought and language is resolved in the productive act of knowledge. Language is a creative product of cognitive function according to the development of the human brain. It happens while maintaining a modal resonance of its constitution in sensitive and perceptive world contact. Each of its units gives access to this phenomenon.
\end{abstract}

Keywords: Language, Thought, Phenomenology, Relation, quantum, Trope, (poetic) Grammar

\section{Introduction}

Language is an object that requires immersion in the energy producing and containing it. That's why it involves its own method of study, which gives it a specific character when considering it scientifically. The speech act presupposes a deep and immemorial saying or dictum never to be achieved (Jaspers, Levinas) though it renews every word in the language. That's why thinkers such as Herder, Humboldt, Gustav Gerber or Nietzsche, consider that speech contacts activate the energy contained in words or give them a new energy if they lost theirs in the so-called entropic process caused by their continuous utterance. It happens so, for example, on repeating the once original metaphors as a cliché. A singular use of its value, such as the poetic one, renews metaphors.

Such energy is intersubjective and transcendent since it appears mentally in an existential environment common to every man. A singular relationship with things, life circumstances and action developing the human faculty of knowledge is thus established. We call this relationship objective thus placing the mental phenomena so-produced in the senses and in the intellectual perception and judgment that they induce in Reason. Its rational foundation is also singular intuition formerly non-existent and endowed with significant intention by the fact of naming beings and turning them into objects of sense. This phenomenon is a linguistic sign. The intuition originating it is also complex. It reverses itself on thought discovering in it a creative capacity. This is why we should consider language, as Amor Ruibal says, the "point of convergence" between Man and the world [1]. Things are now phenomena turning into objects of knowledge in the ontological saying entailed in such an act. This intuition is specifically verbal. It overcomes the contrast established by Kant between intuitive understanding (intellectus ectypus) and reflective one (intellectus archetypus) [2] since it delimits as a objectified word the discursive thought function thus determining its original indeterminacy.

\section{Poietic Energy}

These assumptions lead us to study language in its genesis and formation, in nuce or in fieri, and as something already made, as Amor Ruibal proposes [3]. And this allows us to consider the word footprint or mental gramma of that special intuition already endowed with saying and objective intention. In-between both phenomena some time passes in human evolution, according to anthropological research. In this process we discover, and in the words of Amor Ruibal, "a truly prodigious stream of psychic life between the speaker and the listener" [4]. This is the convergent background of thought and language.

The verbal act is retroprojective. It progresses by replicating itself and always saying something new to the thing previously said but never in its perfection. It evolves, differs, varies, but the internal relationship of elements and basic functions are constant, appropriate, adequate and opportune, although they are also mutable, or plastic. It is, as it is usually said now from a neurological point of view, the epigenic perspective of language.

Amor Ruibal at the beginning of the 20th century (some years before Saussure) systematized these characters to 
describe its overall structure. They are still the scientific "dawn" of linguistic study. To say "word" is to surround thought by deploying it. Words limit Space (S) articulated in Time (T) and Mode (M) of existence.

The merge of Space-Time (S-T) on articulatory Mode (M) - the discreet character of the fission or the implicit, atomic, or so-to-say the quantum of language (it is on an $u b i$ at the time it is projected into another and it covers itself holding the poles and the levels so correlated) - allows us to analyze its constitution. In this you can discover a three-phase process of stress (diátasis), separation (diairesis, diástase) and distribution or diátaxis [5]. They are homologous of the enzyme catalysis by organic fermenting phases, a type of enzyme or vital yeast, as indicated by the Greek word enzume. If we consider, therefore, all verbal Term (Tm) as a product of a catalysis in the coordinates of internal Movement, Actions or expansive Mutation-relational speed included even in the stillness-, we can assist at its evolutionary process as Name (N) constituted in Relationship (R) and modally correlated effect: N-Tm (R) > Noun (Adjective) or Tm (R) > Verb (Adverb). The Name, or the nominal donation (Husserl's Sinngebung), implies a relationship of Mode (wie), Noun, Verb, Determinant, Adjacent, Complement categories. This Relationship presupposes, in turn, ontological inscription of being as an individual in the World, a beating and stressing inscription. The Name has a surrounded and, at the same time, expanded action effect. There is a pronominal instant in the thought, a PRO factor, anaphoric and cataphoric from left and right, up and down, horizontal and vertical. It creates a phonemic volume.

The nucleus S-T of the word proceeds qualitatively and happens in existential Mode. Its resonance is the tone. Therefore, the articulated quantity is based on a point and principle that is present resounding in all acts of language. It is the poetic gramma or pre-scientific germ of language [6]. We do not know the origin of language, but it manifests itself in the basis of any speech act. And with this you can see that a phenomenological Linguistics or a linguistic Phenomenology can be made [7]. Language and thought require each other in the cognizant act: "Think and talk are simultaneous acts. The development of either of both is the one with the other", writes Karl Jaspers [8]. And knowledge contains poietic energy or an internal saying that is already an intentional act and the transit of one element into the other. That's why the word is, according to Gerber, Michel Bréal and Amor Ruibal, a trope.

\section{A Singular Inherency}

The Name is to be considered as a term affected in its root by means of a modal relative Function (F) which is explicitly reverberating in an environment, situation or circumstance, that is: N-Tm (R) F. The nominal value of the lexeme is specified as a noun or verb according to discursive understanding perception just as this takes the object of knowledge itself in a process in which the action is perceived or objectified. This explains the reason why Chomsky considers a "functional head" $\left(v^{*}\right)$ in the "full argument structure" of the verbal transitivity or element that determines the value of the root [9]. Noun and Verb are nominal roots on PRO tension (diátasis) that differs and separates (diástasis) distributing itself (diátaxis) by paradigms according to a lexical Category $(\mathrm{Clx})$. The process can be represented in the following way:

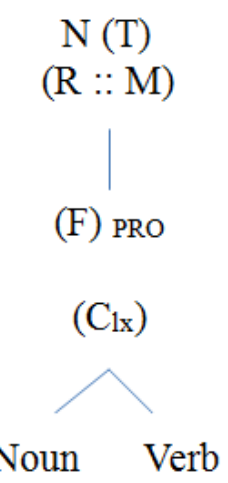

Language is a vital act in a modally relative tension of knowledge. It processes the dynamism of Being, its science. The motion of knowledge transforms the human sound into voice or phonemic unit. The sound action establishes a unit in which the sound waves become relational function of object-subject or ontological principle of knowledge. It is something new that reverses on the faculty allowing it and affecting its original energy. Its unity establishes an irradiation here-there-PRO - by which sound acquires a phenomenological rhythmic depth, a topological and indeterminate principle of inherent and multiple correlation.

The correlation of sound equivalences induced by the ontological contains an implied, constant and durable association in which it is permanently inherent. It changes, mutates, but remains correlated in change and equivalence. In language there is an ongoing "relationship of origin", writes Amor Ruibal [10], meaning with origin the outbreak or articulated product and the direction to element enabling and conditioning it, even if we don't know their beginning. "Origin without origin", adds Jocelyn Benoist expounding Husserl's theory of meaning [11], but expounding it as well with a principle whose highlight is a molten unity of thought and transformed sound. This constitutes the significant and typological unit or the phonetic quantum (phono-phonological and iconic amalgam of voice) of linguistic motion. Another element of body action - articulated sound - displays other active factors of human behavior. With this a horizon of completeness is open. All terms are integrated in it with a certain tension (phrase, clause, proposition: German Satz 'leap') and forming a new unit thus giving meaning. The characters and terms integrated in this way possess the quality that, when analyzed, discloses its constituent principle. They have sense orientation. And this orientation is its name. It occurs in an intentional relationship of something unspecified being determined by integrating itself into a new unit. It is an internal and interpretative (i) factor or nominal (n) constitution of clause, sentence, proposition (p). We represent it as $i \mathrm{p} / n$. The name displays a horizon of correlative integration [12]. 
The articulated motion acquired at a particular moment involves significant inherency. Its presence executes the ontological principle as tropic and existential framework of knowledge: Bild, entfreming, sheme, Ge-stel, etc. Such a phenomenon cannot be reduced to a simple abstraction. Nor can its dynamism be suspended, because such an act is the deployment of inherence thus remaining its attribute. It involves a certain vital color which in some way or another goes as a predicate in some of its determinations.

In the verbal quantum thus elucidated you can find, therefore, the qualitative tension of its foundation, the theme as such. Theory is its praxis, and vice versa. Amor Ruibal insinuates therefore that language is text because of its objective constitution in the phonetic type. And all tension is due to rhythm. It is the fusion and fission point of the articulated S-T according to its Mode of existence. Each language contains a fundamental thoroughly resonance that constitutes it. It is cosmic energy. This resonance responds to the tropical character of language. Language is a trope. It always means more than said, as Nietzsche, Bréal, Amor Ruibal, Gerber, Georg Santayana, Jaspers and Ortega y Gasset, and others would say.

\section{Conclusion}

Grammar is then revealed as tropology of thought. Language considered in the way stated above founds a new mental orb in the universe and guides its study towards the cognizant germ. It is poetic grammar.

\section{References}

[1] Amor Ruibal, Ángel, Cuatro Manuscritos Inéditos. Madrid: Editorial Gredos, 1964, p. 459.

[2] Kant, Immanuel, Kant's Werke, Band V, Kritik der praktischen
Vernunft. Kritik der Urtheilskraft. Berlin: Georg Reimer, 1913, p. 408.

[3] Amor Ruibal, Ángel, Los Problemas Fundamentales de la Filología Comparada. Su Historia, su Naturaleza y sus Diversas Relaciones Científicas, Segunda Parte. Madrid: Fernando Fé, 1904-1905, Imprenta y Encuadernación de la Universidad Pontificia, Santiago (de Compostela), 1905. Edic. Facsímil, Santiago: Consello da Cultura Galega, 2005, p. 348.

[4] Amor Ruibal, Ángel, Los Problemas Fundamentales de la Filología Comparada, op. cit. p. 336.

[5] Domínguez Rey, Antonio, El Drama del Lenguaje. Madrid: Editorial Verbum, 2003, p. 295.

[6] Domínguez Rey, Antonio, El Gramma Poético. Germen Precientífico del Lenguaje. Barcelona: Anthropos Editorial, 2014.

[7] Domínguez Rey, Antonio, Lingüística y Fenomenología. (Fundamento Poético del Lenguaje). Madrid: Editorial Verbum, 2009.

[8] Jaspers, Karl, Die Sprache. Über das Tragische. München: Piper, 1947, p. 44.

[9] Chomsky, Noam, “On phases”, MIT, 26 September 2005, p. 10,

[10] http://www.fosssil.in/Chomsky_Phases.pdf

[11] Amor Ruibal, Ángel, “¿Lengua o dialecto?”, Album Literario 1907 da Asociación Iniciadora e Protectora da Real Academia Galega da Habana. A Coruña: Universidade da Coruña, Real Academia Galega, Xunta de Galicia, 2001, p. 24 [23-26].

[12] Benoist, Jocelyn, "L'identité d'un sens: Husserl, des espèces à la grammaire", in Jocelyn Benoist, Robert Brisart, Jacques English, Liminaires Phénoménologiques, recherches sur le développement de la théorie de la signification de Husserl. Bruxelles: Publications des Facultés Universitaires Saint-Louis, 1998, p. 220 [219-271].

[13] Domínguez Rey, Antonio, Texto, Mundo, Contexto : Intersticios. (Génesis Discursiva). Madrid: UNED, 2012, p. 170 . 